\title{
Pediatric Dental Management in COVID-19 Era: A Contemporary Outlook
}

\author{
Gyanendra Kumar ${ }^{1}$, Francisco Ramos-Gomez ${ }^{2}$, Jatinder K Dhillon ${ }^{3}$, Neetika Singh ${ }^{4}$, Ferah Rehman ${ }^{5}$
}

\begin{abstract}
The pandemic of coronavirus disease-2019 (COVID-19), which originally started in Wuhan city of China, has become a major public health challenge for not only China but also other countries around the globe. The World Health Organization announced that the outbreaks of the novel coronavirus have constituted a public health emergency of international concern. Infection control measures are necessary to prevent the virus from further spreading and to help control the pandemic situation. The risk of cross-infection may be high between dental practitioners and patients because of the unique nature of functioning of dentistry especially pediatric dentistry. Therefore, we require urgent implementation of strict and effective infection control protocols for dental practices and hospitals in nations inflicted with COVID-19. This paper will provide some basic preventive measures required in pediatric dental settings and management protocols for dental practitioners and students to prevent the spread of the COVID-19 nosocomial infection in (potentially) affected areas and maintain a healthy environment for patients and dental team.
\end{abstract} Keywords: Hand hygiene, Healthcare professionals, Pediatric dentistry, Personal protective equipment. Journal of South Asian Association of Pediatric Dentistry (2021): 10.5005/jp-journals-10077-3073

\section{INTRODUCTION}

Coronavirus disease-2019 (COVID-19) had been identified as a novel respiratory disease that causes a huge number of manifestations by the World Health Organization (WHO). ${ }^{1}$ As there are numerous types of coronavirus, alluding to it just as "Coronavirus" is general; hence, the Centers for Disease Control and Prevention (CDC) and WHO energize specialists use COVID-19 while alluding to this new infection, as a novel coronavirus that has not previously been seen in humans. In COVID-19, "CO" stands for "corona", "VI" for "virus", " $D$ " for disease, and 19 indicating the year of discovery. Coronavirus disease 2019 (the disease) is caused by severe acute respiratory syndrome coronavirus 2 , abbreviated to SARS-CoV-2. Till now the spread has been to 215 countries, ${ }^{2}$ leading the WHO to declare COVID-19 a pandemic on March 11, 2020 and a public health emergency worldwide. ${ }^{3}$ Most of the COVID-19 patients represent with mild symptoms such as dry cough, sore throat, and fever. Children influenced with SARS-CoV-2 regularly address with vague manifestations like fever, exhaustion, migraine, myalgia, hack, nasal clog, ageusia, sore throat, windedness or trouble breathing, stomach torment, looseness of the bowels, queasiness, heaving, helpless hunger or may have asymptomatic portrayal. However, the most common symptoms in children are cough and/or fever. ${ }^{4-8}$ It was found that $16-45 \%$ of SARS-CoV-2 infected children had been asymptomatic., ${ }^{9,10}$ The signs and symptoms of COVID-19 in pediatric patients are similar to other infections and noninfectious diseases, including influenza, streptococcal pharyngitis, and allergic rhinitis. ${ }^{11}$ The lack of classical signs or symptoms and a considerable proportion of asymptomatic infection make screening of SARSCoV-2 based on symptoms in children quite challenging. With longer incubation period (2-14 days) ${ }^{12}$ and nonspecific symptoms of child patients, they can be considered as potential carriers of COVID-19 unless tested otherwise. In a study conducted by Qiu et al. including 36 pediatric COVID-19 positive patients, 10 patients (28\%) were found to be asymptomatic coming from a family with an adult member who was infected, symptomatic, or gave recent travel history to an endemic region. ${ }^{13}$ This lends concern
${ }^{1}$ Department of Pediatric and Preventive Dentistry, Maulana Azad Institute of Dental Sciences, New Delhi, India

${ }^{2}$ Department of UCLA School of Dentistry, University of California Los Angeles, Los Angeles, California, USA

${ }^{3}$ Department of Pediatric Dentistry, Nova Southeastern University, Florida, USA

${ }^{4}$ Department of Pediatric and Preventive Dentistry, Bhojia Dental College and Hospital, Baddi, Himachal Pradesh, India

${ }^{5}$ Department of Pedodontics and Preventive Dentistry, Maulana Azad Dental College and Hospital, New Delhi, India

Corresponding Author: Gyanendra Kumar, Department of Pediatric and Preventive Dentistry, Maulana Azad Institute of Dental Sciences, New Delhi, India, Phone: +91 9654700978, e-mail: gyanendrasaroj@ gmail.com

How to cite this article: Kumar G, Ramos-Gomez F, Dhillon JK, et al. Pediatric Dental Management in COVID-19 Era: A Contemporary Outlook. J South Asian Assoc Pediatr Dent 2021;4(1):33-40.

Source of support: Nil

Conflict of interest: None

that children, even if asymptomatic, may play a significant role in community transmission of the COVID-19 virus. Cruz and Zeichner proposed that pediatric patients have a role in transmission in local area. ${ }^{14}$ They noted that children are more likely to have upper respiratory tract involvement, with prolonged respiratory and fecal shedding than adults. According to a recent systematic review done by Hoang including 131 studies published across 26 countries comprised of 7,780 pediatric patients presenting COVID-19 infection symptoms. Fever (59.1\%) and cough (55.9\%) were the most frequent symptoms found in children but $19.3 \%$ of children were carriers without active infection. ${ }^{15}$ Coronavirus disease 2019 has the potential for transmission via respiratory droplets and splatter (aerosol) from saliva and blood of the patients in contact with mucous membranes and infected fomites. ${ }^{16,17}$ This leaves dental professionals in potentially high-risk situations. Young children may not be present with severe classical symptoms of the infection but

\footnotetext{
(c) The Author(s). 2021 Open Access This article is distributed under the terms of the Creative Commons Attribution 4.0 International License (https:// creativecommons.org/licenses/by-nc/4.0/), which permits unrestricted use, distribution, and non-commercial reproduction in any medium, provided you give appropriate credit to the original author(s) and the source, provide a link to the Creative Commons license, and indicate if changes were made. The Creative Commons Public Domain Dedication waiver (http://creativecommons.org/publicdomain/zero/1.0/) applies to the data made available in this article, unless otherwise stated.
} 
may remain vulnerable to it posing a significant transmission risk in the community. ${ }^{18}$ Pediatric dentists providing oral care to children must understand the current local, regional, and national guidelines in the present uncertain scenario and must adapt to changes to ensure safety for dental care providers and patients.

This paper will provide some basic preventive measures required in pediatric dental settings that can be implemented globally. Further, this paper will give an insight into management protocols for dental practitioners and students of developing countries utilizing the guidelines being followed in developed countries to prevent the spread of the COVID-19 nosocomial infection in (potentially) affected areas and maintain a healthy environment for patients and dental teams.

\section{Preventive Measures during COVID-19}

\section{Public Awareness on Dental Services during COVID-19}

A clear message for the general public in their local language should be given through social, digital platforms informing individuals that routine dental care is not available during the COVID-19 pandemic and issuing an advisory about what is to be done in case of a dental emergency. This includes educational material for emergency management of traumatic dental injuries and emphasis on preventive home oral hygiene. Patients can utilize teledentistry for consultation of their problems rather than in-office consultation during this pandemic. Dentists can decide if the patients require urgent dental care in the dental office or defer the treatment for some time if it is nonurgent or prescription of analgesic and antibiotic can cure the problem of the patient. All the urgent procedures are listed in Table 1.

In the case of an emergency requiring complete endodontic therapy (i.e., acute dental pain with irreversible pulpitis), dentists can use a micromotor in place of an air rotor handpiece. A rubber dam with high volume suction is advised, and both the dentist and assistant should do this wearing PPE. In the case of chronic periapical periodontitis, where the patient experiences sharp pain while chewing food, antibiotics such as amoxicillin or cephalosporin and analgesics such as ibuprofen may be advised for the same. Various drugs for the management of dental problems during the COVID-19 pandemic are shown in Figure $1 .^{19}$

Table 1: Guidance table to categorizing dental treatments during COVID-19 pandemic

\begin{tabular}{|c|c|c|c|}
\hline \multicolumn{4}{|c|}{ Dental management category for pediatric patients } \\
\hline Emergency treatment & $\begin{array}{l}\text { Minimally invasive procedures and } \\
\text { without aerosol generation }\end{array}$ & $\begin{array}{l}\text { Invasive and/or aerosol-generating } \\
\text { procedures }\end{array}$ & Elective \\
\hline $\begin{array}{l}\text { Unstable maxillofacial fractures } \\
\text { can compromise the pediatric } \\
\text { patient's airway }\end{array}$ & $\begin{array}{l}\text { Tooth extraction due to severe } \\
\text { dental pain from pulpal } \\
\text { inflammation }\end{array}$ & $\begin{array}{l}\text { Severe dental pain from pulpal } \\
\text { inflammation, pulpectomy, } \\
\text { pulpotomy, partial pulpotomy, } \\
\text { single sitting root canal }\end{array}$ & $\begin{array}{l}\text { Initial or periodic oral } \\
\text { examinations and recall visits }\end{array}$ \\
\hline $\begin{array}{l}\text { Dental trauma with avulsion/ } \\
\text { luxation }\end{array}$ & $\begin{array}{l}\text { Fractured vital teeth that can } \\
\text { be managed without aerosol } \\
\text { generation }\end{array}$ & $\begin{array}{l}\text { Severe dental pain from the } \\
\text { fractured vital tooth (Ellis Class } \\
\text { III, IV) and dental trauma with } \\
\text { avulsion/luxation that needs } \\
\text { invasive/aerosol-generating } \\
\text { procedures }\end{array}$ & $\begin{array}{l}\text { Esthetic dental procedures } \\
\text { Removable orthodontics } \\
\text { appliances/semi-fixed } \\
\text { orthodontics appliances- } \\
\text { adjustment or repairs } \\
\text { Fixed orthodontic treatment }\end{array}$ \\
\hline $\begin{array}{l}\text { Diffuse soft tissue bacterial } \\
\text { infection with intraoral or } \\
\text { extraoral swelling that can } \\
\text { compromise the pediatric } \\
\text { patient's airway }\end{array}$ & $\begin{array}{l}\text { Surgical postoperative osteitis or } \\
\text { dry socket, pericoronitis }\end{array}$ & $\begin{array}{l}\text { Dental restorations (anterior/ } \\
\text { posterior) }\end{array}$ & $\begin{array}{l}\text { Restorative treatment of } \\
\text { asymptomatic teeth }\end{array}$ \\
\hline $\begin{array}{l}\text { Uncontrolled postoperative } \\
\text { bleeding }\end{array}$ & $\begin{array}{l}\text { Localized dental/periodontal } \\
\text { abscess }\end{array}$ & $\begin{array}{l}\text { Debonded fixed stainless steel } \\
\text { crown/zirconia crown cleaning } \\
\text { and temporary cementation }\end{array}$ & Extraction of asymptomatic teeth \\
\hline $\begin{array}{l}\text { Feeding appliances if an } \\
\text { emergency }\end{array}$ & $\begin{array}{l}\text { Fractured or defective fixed } \\
\text { orthodontic appliance, space } \\
\text { maintainers, removable partial } \\
\text { dentures causing soft tissue } \\
\text { laceration }\end{array}$ & $\begin{array}{l}\text { Removable orthodontics } \\
\text { appliance/SS crown adjustments } \\
\text { for radiation/oncology patients }\end{array}$ & $\begin{array}{l}\text { Orthodontic procedures other } \\
\text { than those in category B/C } \\
\text { Placement of SS crown/zirconia } \\
\text { crown }\end{array}$ \\
\hline $\begin{array}{l}\text { Postextraction bleeding that the } \\
\text { patient cannot control with local } \\
\text { measures }\end{array}$ & & $\begin{array}{l}\text { Fractured or defective fixed space } \\
\text { maintainers causing soft tissue } \\
\text { injury }\end{array}$ & $\begin{array}{l}\text { Routine dental cleaning and } \\
\text { preventive therapies including } \\
\text { sealants and topical fluoride }\end{array}$ \\
\hline $\begin{array}{l}\text { Orodental conditions are likely } \\
\text { to exacerbate systemic medical } \\
\text { conditions }\end{array}$ & & Acute periodontal disease & $\begin{array}{l}\text { Replacement of missing tooth/ } \\
\text { teeth with fixed or removable } \\
\text { appliances }\end{array}$ \\
\hline Suspected oral cancer & & Use of LASER & Extraction of asymptomatic tooth \\
\hline & & & $\begin{array}{l}\text { Dental minor surgery. All type of } \\
\text { frenectomy, treatments required } \\
\text { under conscious sedation }\end{array}$ \\
\hline
\end{tabular}


- For dental infection in children, either:

- amoxicillin (250 mg capsules, or Oral Suspension* $125 \mathrm{mg} / 5 \mathrm{ml}$ or $250 \mathrm{mg} / 5 \mathrm{ml}$ ) dose depending on age (see below); three times daily,

\begin{tabular}{ll|ll}
$6-11$ months & $125 \mathrm{mg}$ & $\begin{array}{l}5-11 \text { years } \\
12-17 \text { years }\end{array}$ & $500 \mathrm{mg}$ \\
$1-4$ years & $250 \mathrm{mg}$ & $500 \mathrm{mg}$
\end{tabular}

For severe infection in children aged 6 months to 11 years, increase the dose of amoxicillin up to $30 \mathrm{mg} / \mathrm{kg}$ ( $\max 1 \mathrm{~g}$ ) three times daily. For severe infection in children aged 12-17 years, double the dose of amoxicillin.

or

- phenoxymethylpenicillin (250 mg tablets, or Oral Solution*, $125 \mathrm{mg} / 5 \mathrm{ml}$ or $250 \mathrm{mg} / 5 \mathrm{ml}$ ) dose depending on age (see below); four times daily,

\begin{tabular}{ll|ll}
$6-11$ months & $62.5 \mathrm{mg}$ & $6-11$ years & $250 \mathrm{mg}$ \\
$1-5$ years & $125 \mathrm{mg}$ & $12-17$ years & $500 \mathrm{mg}$
\end{tabular}

For severe infection in children up to 11 years, increase the dose of phenoxymethylpenicillin up to $12.5 \mathrm{mg} / \mathrm{kg}$ four times daily. For severe infection in children aged 12-17 years, increase the dose up to $1 \mathrm{~g}$ four times daily.

or

- metronidazole (200 mg tablets, or Oral Solution*, $200 \mathrm{mg} / 5 \mathrm{ml}$ ) dose depending on age (see below); three times daily unless indicated below

\begin{tabular}{ll|ll}
$1-2$ years & $50 \mathrm{mg}$ & $7-9$ years & $250 \mathrm{mg}$ \\
$3-6$ years & $100 \mathrm{mg} \mathrm{(2 \times daily)}$ & $10-17$ years & $200 \mathrm{mg}$
\end{tabular}

*Sugar-free preparation is available.

Fig. 1: Dental problems during COVID-19 pandemic as given by Scottish Dental Clinical Effective Programme (SDCEP) NHS Education of Scotland

\section{General Precautionary Steps to be Taken in the Dental Clinic}

The following measures are based on the CDC and The National Institute for Occupational Safety and Health (NIOSH)-HIERARCHY OF CONTROLS. The hierarchy simply means that the measures at the top are more effective and protective than the ones at the bottom. The measures include elimination, substitution, use of engineering controls, administrative controls, and effective use of PPE as depicted in Figure $2 .{ }^{20}$

Elimination and substitution are the most effective and difficult to adapt, as it requires a major change in practices as well as in the design of the work environment. It includes screening patients before entering the office, identifying suspected positive COVID-19 cases, and the use of teledentistry. Tele dentistry is a form of distant consultation and triage service which includes advice, analgesia, and antimicrobials ( $A A A$ ) that should be given to all the patients. If there is an emergency and treatment cannot be delayed, then only the patient is asked to visit the dental center for direct in-person consultation and treatment by a pediatric dentist.

Engineering controls are the next level of the hierarchy of controls and begin when a patient enters the waiting area. If patients are traveling by car, they should be encouraged to stay in their car until they can be seen. Enough room for accommodating an accompanying person should be present in the healthcare facility or clinic facilitating social distancing. Appointments should be staggered to have less the number of patients at any given time and allow for adequate disinfection of the operatory and waiting area. Only one accompanying person should be allowed in the waiting area per child patient. Chairs should be separated 6 feet apart for the maintenance of social distance. On entering the clinic, the receptionist should instruct all visitors to wash their hands or use hand sanitizer and should provide a mask for patients to wear. They should also ask patients to follow proper respiratory hygiene. ${ }^{21}$ The patient's and his/her parent/guardian's body temperature should be assessed using a noncontact thermometer, and treatment should only be provided if the patient's temperature is $<100.4^{\circ} \mathrm{F}$. A complete history should also be obtained regarding recent travel to areas experiencing high COVID-19 cases, the presence of any symptoms of a respiratory infection such as fever and/or sore throat, and any contact with COVID-19 positive individuals. In case the patient's temperature is $>100.4^{\circ} \mathrm{F}$, he/she should be referred to a nearby COVID center for a COVID-19 test. If he/she has pain, antibiotics and analgesics can be provided for pain relief (Fig. 1).

Waiting rooms should be well-ventilated $(60 \mathrm{~L} / \mathrm{s}$ per patient is considered adequate ventilation). ${ }^{22}$ Engineering controls may also include improved ventilation rates and the use of negative pressure ventilation. Airborne exposure of COVID-19 viral particles must be controlled as they transmit through air. Therefore, changes incorporated into building structural frameworks, such as heating, and cooling frameworks and creating vents for ventilation, can lessen the exposure of virus through the airway thereby reducing the danger of transmission. ${ }^{23}$ Physical barriers, such as clear plastic wheeze guards and a drive-through window for patient assistance must be installed. Staff at the reception should wear a fluid-resistant surgical mask if they are unable to maintain a 2-m separation socially. 


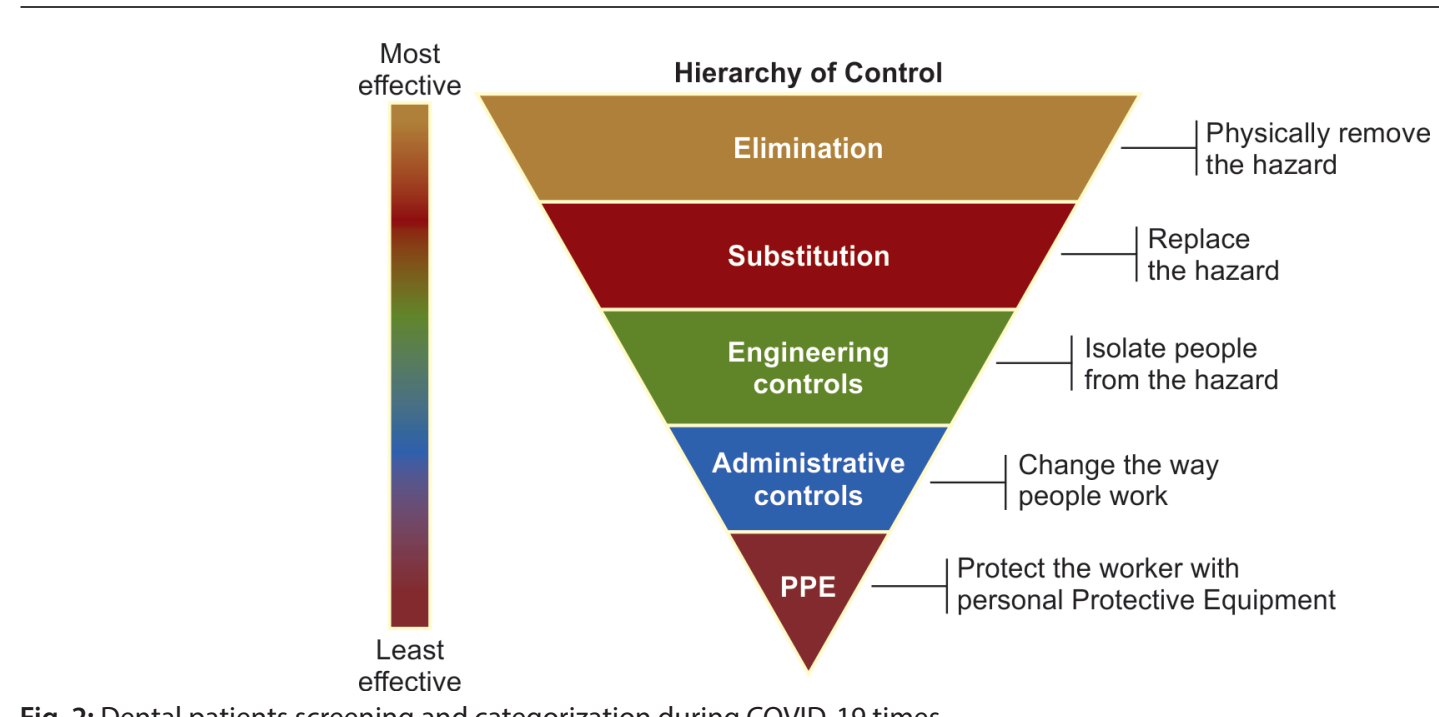

Fig. 2: Dental patients screening and categorization during COVID-19 times

\section{Administrative Controls}

The next level, administrative controls, relies on the worker or employer to implement changes in work policies or procedures to minimize exposure. There should be a clearly outlined plan for communication and provision for the use of teledentistry. Employees should report in shifts to reduce the risk of crossinfection, and anyone suspected of being ill should be encouraged to stay home. All workers should be trained appropriately about COVID-19. Additionally, implementing the previously described minimally invasive procedures reduce the risk of exposure at this level.

\section{Personal Protective Equipment}

Personal protective equipment (PPE) includes various equipment such as gloves, protective eyewear, face shields, surgical face masks/N-95 masks, and respirators. In view of the area and danger level, PPE will vary, so employers should consistently check the OSHA and CDC guidelines for recent updates (Table 2). It is highly recommended to use PPE, such as disposable scrubs and gown, gloves, goggles, face shields, disposable shoe covers, and masks. ${ }^{17,24,25}$ Surgical masks have been fabricated with a single direction protection design capturing the body fluids leaving the person wearing it thereby shielding the patient from the danger of cross-contamination. ${ }^{26}$ Filtering facepiece (FFP) mask is recommended to be used in dentistry for airway protection. Filtering face-piece masks are intended to obstruct infection particles and are categorized depending on their filtration adequacy toward particles $\geq 0.3 \mu \mathrm{m}$ in width: FFP1 (80\% filtration viability), FFP2 ( $94 \%$ filtration viability), and FFP3 (99\% filtration adequacy). ${ }^{27}$ The diameter of COVID-19 air droplet particles are expected to be 0.06 to $-0.14 \mu \mathrm{m},{ }^{28} \mathrm{FFP} 2 / \mathrm{N} 95$, FFP3/N99, and N100 are presumed to be the most effective masks. In dentistry, eye protection is mandatory to protect the eyes from mechanical (e.g., foreign bodies), chemical (e.g., disinfectants), and biological (e.g., saliva, blood, oral fluids) hazards. ${ }^{29}$ Eyes are a common pathway for infection with SARS-CoV-2. Proper eyewear protection with covering frames must be used and should have the maximum possible coverage of the face. Otherwise, a plastic face shield
Table 2: Personal protective equipment (PPE) and their uses in dental care setting*

\begin{tabular}{|c|c|c|c|}
\hline \multicolumn{4}{|c|}{ PPE for COVID-19 urgent dental care settings } \\
\hline & $\begin{array}{l}\text { Waiting room/ } \\
\text { reception }\end{array}$ & $\begin{array}{l}\text { Dental sur- } \\
\text { gery }\end{array}$ & Dental surgery \\
\hline & $\begin{array}{l}\text { No clinical } \\
\text { treatment }\end{array}$ & $\begin{array}{l}\text { Non-AGP } \\
\text { treatment }\end{array}$ & $\begin{array}{l}\text { Treatments } \\
\text { involving AGPs }\end{array}$ \\
\hline $\begin{array}{l}\text { Good hand } \\
\text { hygiene }\end{array}$ & Yes & Yes & Yes \\
\hline Disposable gloves & No & Yes & Yes \\
\hline $\begin{array}{l}\text { Disposable plastic } \\
\text { apron }\end{array}$ & No & Yes & No \\
\hline $\begin{array}{l}\text { Disposable } \\
\text { gown }\end{array}$ & No & No & Yes* $^{*}$ \\
\hline $\begin{array}{l}\text { Fluid-resistant } \\
\text { surgical mask }\end{array}$ & Yes & Yes & No \\
\hline $\begin{array}{l}\text { Filtering facepiece } \\
\text { (FFP3) }\end{array}$ & No & No & Yes \\
\hline \multicolumn{4}{|l|}{ Respirator*** } \\
\hline Eye protection $* * * *$ & No & Yes & Yes \\
\hline
\end{tabular}

*COVID-19 guidelines and standard operating procedures. Urgent dental care system in the context of coronavirus. NHS England and NHS Improvement. Version 1, 15 April 2020 (Publications approval reference:001559)

**Fluid-resistant gowns (or long-sleeved waterproof apron) must be worn during aerosol-generating procedures (AGPs). If non-fluid resistant gowns are used, a disposable plastic apron should be worn underneath

***If wearing an FFP3 that is not fluid-resistant, a full-face shield/visor must be worn

****Eye protection ideally should be disposable, if polycarbonate safety glasses/goggles or equivalent are used, they should be disinfected in line with manufacturers' guidance

AGP, non-aerosol-generating procedures

might be indicated with glasses as it gives a more prominent field of assurance to the face against airborne drops. The face shield can be placed directly on the forehead or as part of the disposable mask. ${ }^{30}$ Centers for Disease Control and Prevention recommends $\mathrm{N}-95$ respirators or higher level mask for suspected/ 
confirmed COVID patients for all procedures that may be aerosol and non-aerosol generating, while for non-COVID patients surgical mask is adequate for non-aerosol-generating procedures (AGPs) and $\mathrm{N}-95$ respirators or FDA approved surgical mask is required for AGPs. ADA recommends NIOSH-certified, disposable N95 FFP respirator or better.

\section{Specific Precautionary Steps to be Taken in the Dental Clinic}

\section{Aerosol Generation}

The transmission of aerosols can be through direct contact while coughing, sneezing, laughing, or talking which leads to the generation of large ( $>5 \mu \mathrm{m}$ diameter) and small $(\leq 5 \mu \mathrm{m}$ diameter) droplets or aerosols. ${ }^{31}$ Larger droplets fall on the ground immediately due to gravitational pull; therefore, for droplet transmission close physical contact between an infected individual and a susceptible individual is required. Based on diameter, aerosols can be distinguished as large and small droplets. Large droplets behave ballistically, fall on the surfaces, and can infect an individual, and this mode of transmission is called "droplet transmission", 32 whereas the "small droplets can remain suspended in the air for a variable amount of time or can disperse in the air as "droplet nuclei" floating freely. Such droplets are responsible for "Airborne transmission". ${ }^{33}$ Each AGP has a different composition and requires different levels of PPE. These procedures can be further classified as aerosol-generating medical procedures (AGMPs) and aerosol-generating dental procedures (AGDPs). ${ }^{34}$ Aerosolgenerating medical procedures utilize intubation that agitates the airway making the patient coughing forcibly and releasing aerosols filled with high-risk SARS-CoV-2 can transmit to healthcare workers. Furthermore, tissues and fluids in the oral cavity consist of bacteria and viruses. Aerosols containing the virus are released during AGDPs with the use of instruments that rotate, vibrate, and release compressed air. Literature has shown that the application of high-volume evacuation (HVE) can decrease dental aerosols by $\sim 90 \% .{ }^{35}$ However, most suctions used in clinics and hospitals are not high volume, and a small percentage of these dental aerosols stay floating freely in the air for at least 10-30 minutes, depending on the operatory airflow. ${ }^{36}$ Aerosols generated consisting of highly virulent pathogens such as SARS-CoV can travel more than six feet and stay noticeable all around for a longer duration because of their low settling speed before they enter the respiratory system or infected surfaces. ${ }^{29}$ In light of the current epidemiological information, COVID-19 has higher contagiousness than SARS-CoV and MERS-CoV, and airborne transmission increases in a relatively closed environment when there is exposure to high concentrations of aerosols. ${ }^{37}$ Hence, urgent modification of standard precautions and disease control regimens focused toward $\mathrm{nCoV}$ is fundamental during this pandemic. ${ }^{38,39}$

In this situation that treatment is required, all equipment and materials ought to be collected in the operatory before seating the patient. Chemomechanical methods for caries removal (e.g., Carisolv and ART techniques) and hand scalers instead of ultrasonic scaling can be used to decrease aerosol generation. ${ }^{40}$ Treatment should be finished in a single visit at whatever point conceivable, and quadrant dentistry should be followed. Intraoral imaging should be limited and extraoral radiographs should be preferred to decrease excessive salivation and gagging. ${ }^{41}$ While taking intraoral
X-rays, sensors should be covered with a double barrier to prevent tearing and cross-contamination. ${ }^{42} \mathrm{~A}$ dental handpiece with an anti-retraction function or any anti-reflux design is enthusiastically suggested. Four-handed technique, high-volume saliva evacuation unit, and a rubber dam must be utilized to diminish conceivable exposure to infectious agents. ${ }^{21}$ With the use of a rubber dam, there is a $70 \%$ reduction in airborne microbes in a 3 feet diameter around the operating zone. ${ }^{43}$

\section{Infection Control in Dental Operatory}

In addition to universal precautions, there are other considerations for infection control during this pandemic. Screening for fever and respiratory symptoms should be done for all staff at the beginning of every shift. Every patient should be considered as a COVID-19 patient capable of transmitting the disease. A preprocedural mouth rinse with $0.2 \%$ povidone-iodine should be done for all the patients, which is effective against coronaviruses that caused SARS and MERS, ${ }^{31}$ or $0.5-1 \%$ hydrogen peroxide, which has vague biocidal action against coronaviruses. It should be noted, however, that $0.02 \%$ chlorhexidine digluconate, one of the most commonly used pre-procedural rinses, was found to be ineffective against coronaviruses by Kampf et al. ${ }^{44}$ Appropriate hand hygiene instructions should be followed, using soap or alcohol-based sanitizers when contact with patients (Fig. 3). ${ }^{45}$ The same should be done after contact with infected surfaces or equipment, and after removing PPE, gloves, protective eyewear, face shields, and N95 or higher-level respirators. The respirator/ cover ought to be eliminated and disposed of before leaving the operatory. If respirators are used, the staff must be well-versed with donning and doffing, and a test should be performed to check proper fitting as shown in Figure $4 .{ }^{45}$

If disposable gowns are used in the operatory, then they have to be changed after every appointment. All cloth gowns, towels, and other soiled linens should be laundered in hot water $\left(60-90^{\circ} \mathrm{C}\right)$ with normal detergent and soaked $0.05 \%$ chlorine for 30 minutes and sun-dried. They should never be taken back home.

Clean and disinfect all the equipment and operatories after each patient as per infection control guidelines. Surface disinfection is done using $0.1 \%$ sodium hypochlorite or $62-71 \%$ ethanol, which essentially diminishes contamination of COVID-19 on surfaces within 1 minute of exposure time. ${ }^{36,46}$

Currently, with strict infection control measures, dental workplaces have been available to offer all dental types of assistance with no announced instances of COVID-19 transmission from patients to dental staff or the other way around. However, there is further need to research this subject. The concept of herd immunity has also taken hold. However, to achieve herd immunity, $70-90 \%$ of the population should get insusceptible to COVID-19 through either natural immunity or vaccination. ${ }^{47}$ With the initiation of vaccination drive and availability of different vaccines worldwide, there is hope that this is a possibility. However, with the shortage in production, vaccine hesitancy, logistic issues, and the recent spread of new variants, this is still a distant goal.

\section{Conclusion}

Pediatric dentists are in a unique position in the current environment, as they are dealing with children and parents at the same time and therefore are at a greater risk of exposure. In 


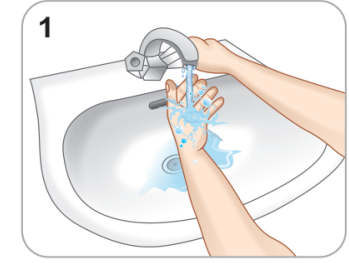

Wet hands with water

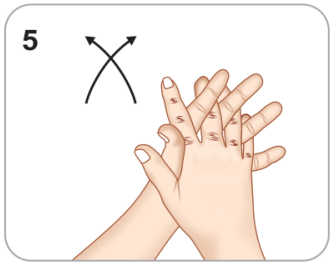

Palm to palm with fingers interlaced

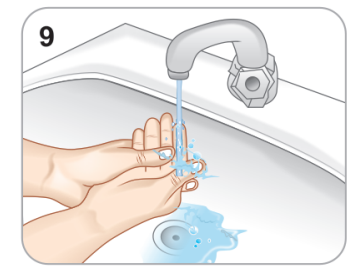

A

Rinse hands with water

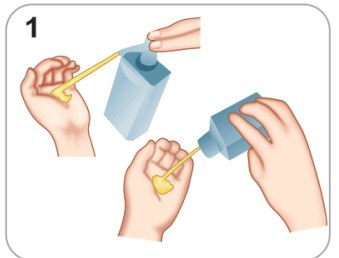

Apply a palmful of the product in a cupped hand and cover all surfaces.

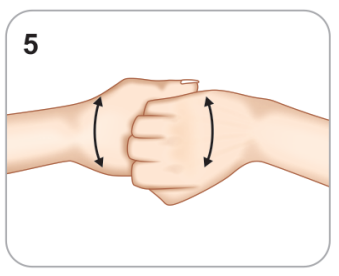

Backs of fingers to opposing palms with fingers interlocked

B

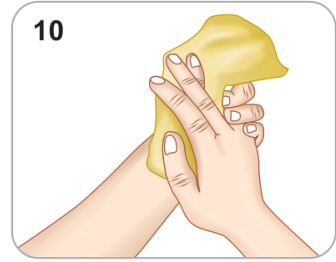

Dry hands with towel

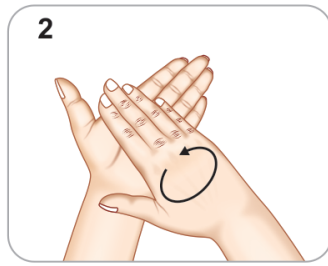

Rub hands palm to palm

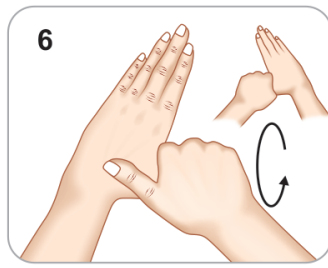

Rotational rubbing of left thumb clasped in right palm and vice versa

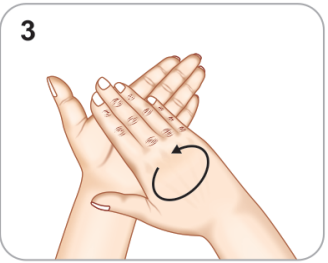

Rub hands palm to palm

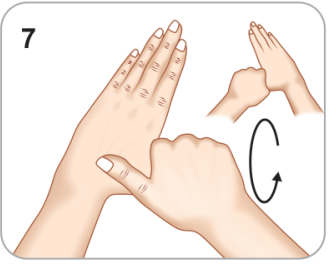

Rotational rubbing of left thumb clasped in right palm and vice versa

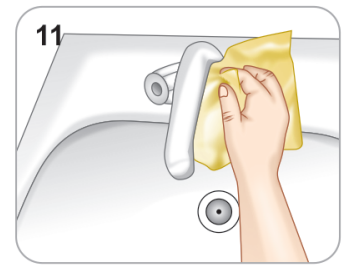

Use towel to turn off faucet

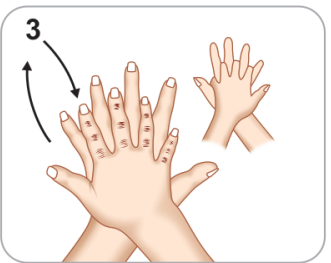

Right palm over the back of the other hand with interlaced fingers and vice versa

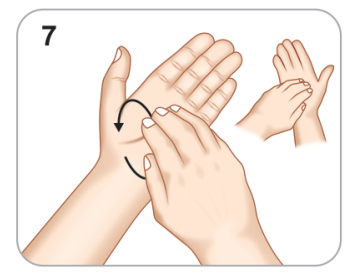

Rotational rubbing, backwards and forwards with clasped fingers of right hand in left palm and vice versa

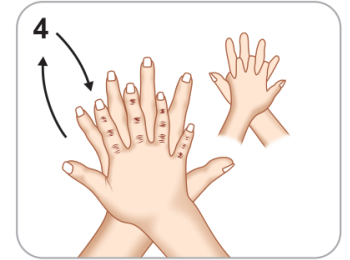

Right palm over the back of the other hand with interlaced fingers and vice versa

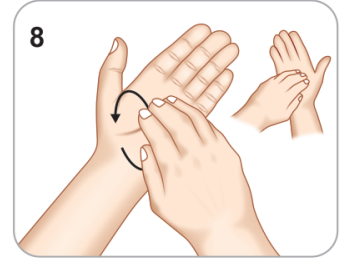

Rotational rubbing, backwards and forwards with clasped fingers of right hand in left palm and vice versa

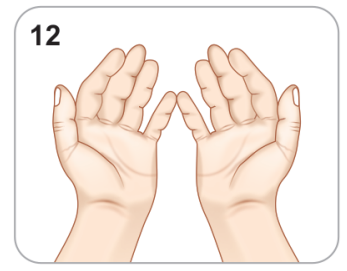

...and your hands are safe

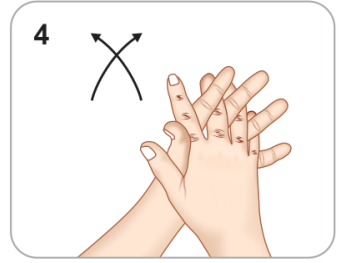

Palm to palm with fingers interlaced

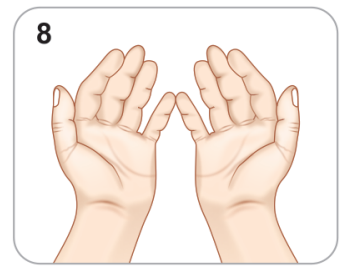

Once your hands are safe

Figs 3A and B: Hand hygiene practices using soap and alcohol based sanitizer* *Public Heath England. Guidance; Reducing the risk of transmission of COVID-19 in hospital setting. Updated 17 April 2020

addition to providing necessary treatment to children, they also have to maintain high standards of infection control and provide guidance for parents. In the coming time, this epidemic will have a tremendous impact on the way we practice dentistry. Thus, it is imperative to have clear guidelines to ensure the safety, not only of patients but also of dental staff. 


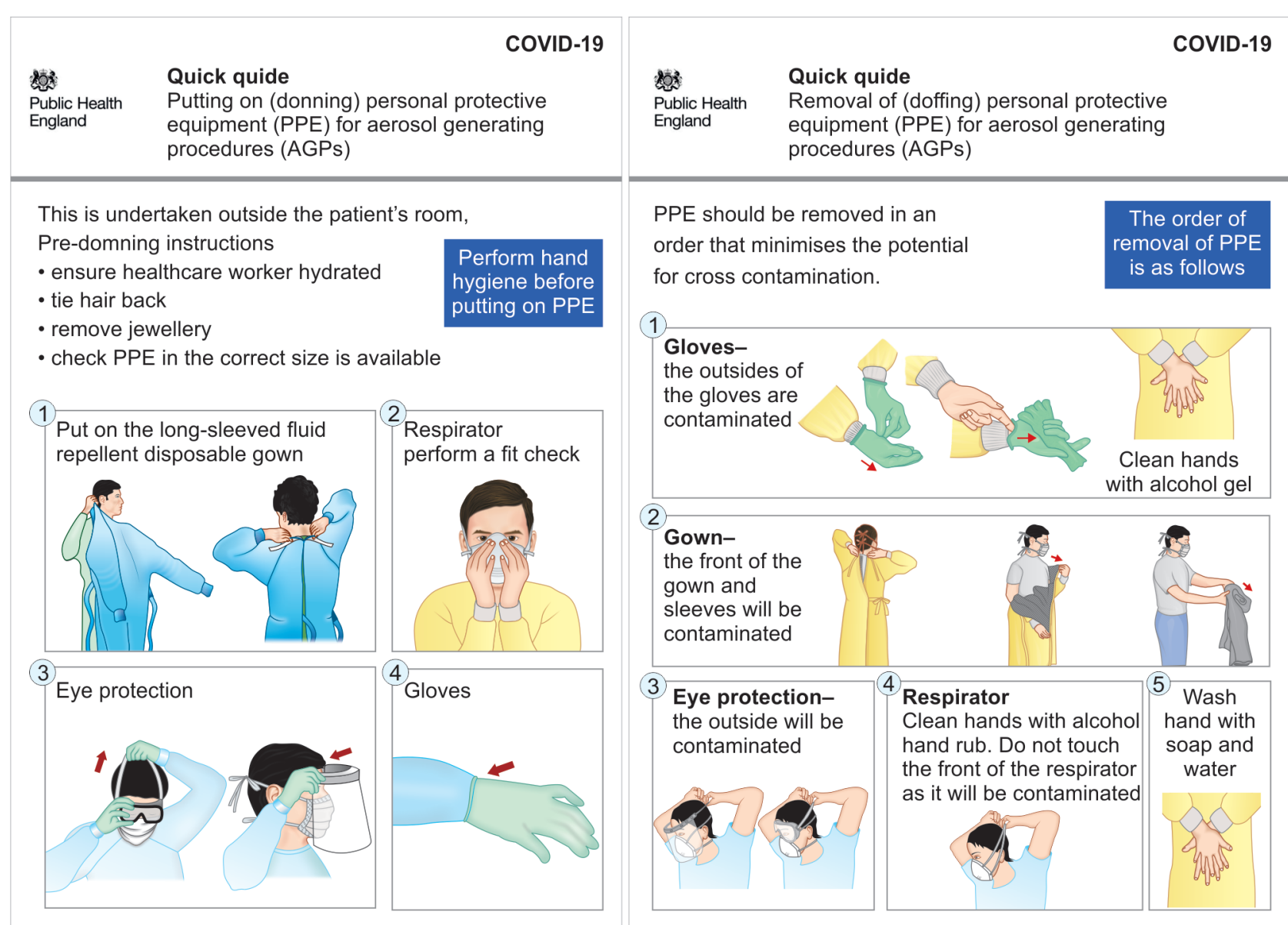

Fig. 4: Quick guide to donning and doffing of personal protective equipments (PPE)* *Public Heath England. Guidance; COVID-19: Personal protective equipment use for aerosol generating procedures. Published 10 January 2020. Last updated 10 April 2020

\section{References}

1. World Health Organization, WHO Director-General's Remarks at the Media Briefing on 2019-nCoV on 11 February 2020; 2020. Available online: https://www.who.int/dg/ speeches/detail/whodirector-general-s-remarks-at-the-media-briefing-on-2019-ncovon-11february-2020.

2. Available online at: http://www.who.int/COVID-19/informationCoronavirus disease 2019 (COVID-19) Situation Report - 78. Data as received by WHO from national authorities by 10:00 CET, 5th May 2020).

3. World Health Organization, WHO Director-General's opening remarks at the media briefing on COVID-19 - 11 March 2020. Available online: https://www.who.int/dg/speeches/detail/who-director-general-sopening-remarks-at-the-media-briefingon-covid-19-11-march-2020.

4. Dong $\mathrm{Y}, \mathrm{Mo} \mathrm{X}, \mathrm{Hu} \mathrm{Y}$, et al. Epidemiological characteristics of 2143 pediatric patients with 2019 coronavirus disease in China. Pediatrics 2020;58(4):712-713. DOI: 10.1542/peds.2020-0702.

5. Foster CE, Moulton EA, Munoz FM, et al. Coronavirus disease 2019 in children cared for at Texas children's hospital: initial clinical characteristics and outcomes. J Pediatric Infect Dis Soc 2020;9(3):373377. DOI: 10.1093/jpids/piaa072.

6. Xu H, Liu E, Xie J, et al. A follow-up study of children infected with SARS-CoV-2 from western China. Ann Transl Med 2020;8(10):623. DOI: 10.21037/atm-20-3192.

7. Shekerdemian LS, Mahmood NR, Wolfe KK, et al. International COVID19 PICU collaborative. Characteristics and outcomes of children with coronavirus disease 2019 (COVID-19) infection admitted to US and
Canadian pediatric intensive care units. JAMA Pediatr 2020;174(9):1-6. DOI: 10.1001/jamapediatrics.2020.1948.

8. Mannheim J, Gretsch S, Layden JE, et al. Characteristics of hospitalized pediatric COVID-19 cases - Chicago, Illinois, March - April 2020. J Pediatric Infect Dis Soc 2020. piaa070.

9. Assaker R, Colas AE, Julien-Marsollier F, et al. Presenting symptoms of COVID-19 in children: a meta-analysis of published studies. Br J Anaesth 2020;125(3):e330-e332. DOI: 10.1016/j.bja.2020. 05.026.

10. Poline J, Gaschignard J, Leblanc C, et al. Systematic SARS-CoV-2 screening at hospital admission in children: a French prospective multicenter study. Clin Infect Dis 2020. ciaa1044.

11. Information for Pediatric Healthcare Providers. Available on: https:// www.cdc.gov/coronavirus/ 2019-ncov/hcp/pediatric-hcp.html, updated on august 14,2020. Accessed September 2, 2020.

12. Huang $C$, Wang $Y, L i X$, et al. Clinical features of patients infected with 2019 novel coronavirus in Wuhan. China Lancet 2020;395(10223):497506. DOI: 10.1016/S0140-6736(20)30183-5.

13. Qiu $\mathrm{H}, \mathrm{Wu}$ J, Hong $\mathrm{L}$, et al. Clinical and epidemiological features of 36 children with coronavirus disease 2019 (COVID-19) in Zhejiang. China Observat Cohort Study Lancet Infect Dis 2020;20(6). DOI: 10.1016/ S1473-3099(20)30198-5.

14. Cruz AT, Zeichner SL. COVID-19 in children: Initial characterization of the pediatric disease. Pediatrics. 2020;145(6):e20200834.DOI: 10.1542/ peds.2020-0834. Epub 2020 Mar 16. PMID: 32179659.

15. Hoang A, Choratha K, Moreirab A, et al. COVID-19 in 7780 pediatric patients: a systematic review. EClinicalMedicine 2020;24:100433. DOI: 10.1016/j.eclinm.2020.100433. 
16. To KKW, Tsang OTY, Yip CCY, et al. Consistent detection of 2019 novel coronavirus in saliva. Clin Infect Dis 2020;71(15):841-843. DOI: https:// doi.org/10.1093/cid/ciaa149.

17. Fan C, Lei D, Fang C, et al. Perinatal transmission of COVID-19 associated SARS-CoV- 2: Should we worry? Clin Infect Dis 2020. ciaa226. Online ahead of print https://doi.org/10.1093/cid/ ciaa226.

18. Mallineni SK, Innes NP, Raggio DP, et al. Coronavirus disease (COVID19): characteristics in children and considerations for dentists providing their care. Int J Paediatr Dent 2020;30(3):245-250. DOI: https:// doi.org/10.1111/ipd.12653.

19. Drugs for the Management of Dental Problems During COVID19 Pandemic. Scottish Dental Clinical Effective Programme (SDcep) NHS Education of Scotland, 8 April 2020 (Last accessed on25 April 2020)] Available online: http://www.sdcep.org.uk/ wp-content/uploads/2020/04/SDCEP-MADP-COVID-19-drugsupplement-080420.pdf.

20. Available online at: https://www.cdc.gov/niosh/topics/hierarchy/ default.html. Last accessed on June 27, 2020.

21. Day M. COVID-19: ibuprofen should not be used for managing 297 symptoms, say doctors and scientists. BMJ 2020;368:m1086. DOI: /10.1136/bmj.m1086.

22. Li Y, Wing-Hong S, Natural Ventilation for infection control in health care settings. WHO (2009). Avaible online: https://www.who.int/ water_sanitation_health/publications/natural_ventilation.pdf.

23. ISHRAE COVID-19 Guidance Document for Air Conditioning and Ventilation. Available at: https://ishrae.in/mailer/ISHRAE_COVID19_Guidelines.pdf.

24. Zhou P, Yang XL, Wang XG, et al. A pneumonia outbreak associated with a new coronavirus of probable bat origin. Nature 2020;579(3):270-273. DOI: 10.1038/s41586-020-2012-7.

25. Meng L, Hua F, Bian Z. Coronavirus disease 2019 (COVID- 19): emerging and future challenges for dental and oral medicine. J Dent Res 2020;99(5):481-487. DOI: 10.1177/0022034520914246.

26. Checchi L, Montevecchi M, MoreschiA, et al. Efficacy of three face masks in preventing inhalation of airborne contaminants in dental practice. JADA 2005;136(7):877-882. DOI: 10.14219/jada. archive.2005.0288.

27. Radonovich LJ, Simberkoff MS, Bessesen MT, et al. N95 respirators vs medical masks for preventing influenza among health care personnel: a randomized clinical trial. JAMA 2019;322(9):824-833. DOI: 10.1001/jama.2019.11645.

28. Zhu N, Zhang $D$, Wang W, et al. A novel coronavirus from patients with pneumonia in China, 2019. N Engl J Med 2020;382(1):727-733. DOI: 10.1056/NEJMoa2001017.

29. WHO. Infection prevention and control of epidemic-and pandemicprone acute respiratory infections in health care. Geneva, Switzerland: World Health Organization; 2014. Available at: https://www.who. int/publications/i/item/infection-prevention-and-control-ofepidemic-and-pandemic-prone-acute-respiratory-infections-inhealth-care

30. Montevecchi $M$, Checchi V, Felice $P$, et al. Management rules of the dental practice: individual protection devices. Dent Cadmos 2012;80(5):247-263. DOI: 10.1016/j.cadmos.2011. 11.007.

31. Eggers M, Koburger-Janssen T, Eickmann M, et al. In vitro bactericidal and virucidal efficacy of povidone-iodine gargle/mouthwash against respiratory and oral tract pathogens. Infect Dis Ther 2018;7(2):249259. DOI: 10.1007/s40121-018-0200-7.
32. Teilleier R, Li Y, Cowling BJ, et al. Recognition of aerosol transmission of infectious agents: a commentary. BMC Infect Dis 2019;19(1):101. DOI: $10.1186 / \mathrm{s} 12879-019-3707-y$.

33. Netz RR. Mechanisms of airborne infection via evaporating and sedimenting droplets produced by speaking. J Phys Chem B 2020;124(33):7093-7101. DOI: 10.1021/acs.jpcb.0c05229.

34. Thamboo A, Lea J, Sommer DD, et al. Clinical evidence based review and recommendations of aerosol generating medical procedures in otolaryngology - head and neck surgery during the COVID-19 pandemic. J Otolaryngol Head Neck Surg 2020;49(1):28. DOI: 10.1186/ s40463-020-00425-6.

35. Harrel SK, Molinari J. Aerosols and splatter in dentistry: a brief review of the literature and infection control implications. J Am Dent Assoc 2004;135(4):429-437. DOI: 10.14219/jada.archive.2004.0207.

36. Ricci ML, Fontana S, Pinci F, et al. Pneumonia associated with a dental unit waterline. Lancet 2012;379(9816):684. DOI: 10.1016/S01406736(12)60074-9.

37. Rothe C, Schunk M, Sothmann P, et al. Transmission of 2019-nCoV infection from an asymptomatic contact in Germany. N Engl J Med 2020;382(10):970-971. DOI: 10.1056/NEJMc2001468.

38. COVID-19 guidelines and standard operating procedures. Urgent dental care system in the context of Coronavirus. NHS England and NHS Improvement. Version 1, 15 April 2020 (Publications approval reference:001559) https://assets.publishing.service.gov.uk/ government/uploads/system/uploads/attachment_data/file/879111/ T4_poster_Recommended_PPE_additional_considerations_of COVID-19.pdf.

39. Cochran MA, Miller CH, Sheldrake MA. The efficacy of 293 the rubber dam as a barrier to the spread of microorganisms during 294 denta treatment. J Am Dent Assoc 1989;119(1):141-144. DOI: 10.14219/jada. archive.1989.0131.

40. Peng X, XuX, Li Y, et al. Transmission routes of 2019-nCoV and controls in dental practice. Int J Oral Sci 2020;12(1):1-6. DOI: 10.1038/s41368020-0075-9.

41. Alharbi A, Alharbi S, Alquidi S. Guidelines for dental care provision during the COVID-19 pandemic. Saudi Dent J 2020;32(4):181-186. DOI: 10.1016/j.sdentj.2020.04.001.

42. Samaranayake LP, Reid J, Evans D. The efficacy of rubber dam isolation in reducing atmospheric bacterial contamination. ASDC J Dent Child 1989;56:442-444.

43. Hu T, Li G, Zuo Y, et al. Risk of hepatitis B virus transmission via dental handpieces and evaluation of an anti-suction device for prevention of transmission. Infect Control Hosp Epidemiol 2007;28(1):80-82. DOI: $10.1086 / 510808$.

44. Kampf G, Todt D, Pfaender S, et al. Persistence of coronaviruses on inanimate surfaces and their inactivation with biocidal agents. J Hospital Infect 2020;104(30):246-251. DOI: 10.1016/j.jhin.2020. 01.022 .

45. Public Heath England. Guidance; Reducing the risk of transmission of COVID-19 in hospital setting. Updated 17 April 2020. Available online: https://www.gov.uk/government/publications/wuhan-novelcoronavirus-infection-prevention-and-control/reducing-the-riskof-transmission-of-covid-19-in-the-hospital-setting\#contents (Last accessed on 23 April 2020).

46. Wang WK, Chen SY, Liu IJ, et al. Detection of SARS- associated coronavirus in throat wash and saliva in early diagnosis. Emerg Infect Dis 2004;10(7):1213-1219. DOI: 10.3201/eid1007.031113.

47. Rubin R. Difficult to determine herd immunity threshold for COVID-19. JAMA 2020;324(8):732. DOI: 10.1001/jama.2020.14785. 